\title{
Deoxyribonucleic Acid Homologies Among Organisms in the Genus Gluconobacter
}

\author{
B. K. MICALES, ${ }^{1}$ J. L. JOHNSON, ${ }^{2}$ AND G. W. CLAUS ${ }^{1 *}$ \\ Department of Biology ${ }^{1}$ and Department of Anaerobic Microbiology, ${ }^{2}$ Virginia Polytechnic Institute and State University, \\ Blacksburg, Virginia 24061
}

\begin{abstract}
The taxonomy of the genus Gluconobacter has undergone many changes during the past $\mathbf{4 0}$ years. Based on phenotypic properties, this genus has changed from numerous species to one species containing five subspecies and then to a single species, Gluconobacter oxydans, with no subspecies. The present study was designed to test the validity of this latter view. Nucleotide sequence similarites were determined for 54 strains of Gluconobacter by using an S1 nuclease procedure. Three distinct deoxyribonucleic acid homology groups were obtained. The average level of relatedness among these groups was $16 \%$. Homology group I contained 32 strains and included the type strain of $G$. oxydans and the type strains of all previously recognized subspecies. Homology group II contained 12 strains that had an intragroup homology level of 44 to $87 \%$ (average, $65 \%$ ) with reference strain IFO 3264. Homology group III contained six strains with an average intragroup homology level of $86 \%$ with reference strain IFO 3276a. Reference strains IFO 3264 and IFO 3276 were previously recognized as $G$. oxydans. The remaining four strains of Gluconobacter had from 0 to $23 \%$ homology with reference strains used to delineate the three homology groups. Although these data show that the genus Gluconobacter is composed of at least three species, they also support elimination of the previously designated subspecies. Three isolates implicated in pink disease of pineapples were shown either not to be gluconobacters or to be mixed with gluconobacters. The occurrence of colony variants within many of the Gluconobacter strains is described, and the significance of this observation is discussed.
\end{abstract}

The genus Gluconobacter is composed of strictly aerobic, gram-negative rods that (i) have the ability to oxidize a wide variety of polyols $(17,25)$, (ii) lack a complete tricarboxylic acid cycle (21), and (iii) grow at low pH (12). Although these unique features aid in the separation of gluconobacters from other bacteria, the subgeneric taxonomy of this genus has not been clearly established.

Asai (2-5), Vaughn (36), Asai and Shoda (8), and De Ley and Frateur (12) proposed various taxonomic schemes for Gluconobacter. All of these proposals were based upon phenotypic data, such as acid production from various carbohydrates, pigmentation, and production of gammapyrones from carbohydrates $(11,12)$. The number of subgeneric taxa proposed by these authors varied from 1 to 13 species (6). In Bergey's Manual of Determinative Bacteriol$o g y, 8$ th ed. (12), De Ley and Frateur list a single species, Gluconobacter oxydans, containing four subspecies $(G$. oxydans subsp. industrius, $G$. oxydans subsp. melanogenus, $G$. oxydans subsp. oxydans, and $G$. oxydans subsp. suboxydans). A fifth subspecies, $G$. oxydans subsp. sphaericus, was later described by Ameyama (1).

Loitsyanskaya et al. (27) examined 56 acetic acid bacteria by using 136 phenotypic features and found that all of the Gluconobacter strains clustered into a single phenon with a simple matching coefficient of $90 \%$. From this, they concluded that the genus Gluconobacter is composed of a single species and that division into separate subspecies is not justified. The same conclusions were reached by Gosselé et al. (20), who investigated 98 strains of Gluconobacter and used 177 phenotypic features plus gel electrophoresis of soluble proteins. These conclusions have recently been published in Bergey's Manual of Systematic Bacteriology, vol. 1 (14).

\footnotetext{
* Corresponding author.
}

The purpose of this investigation was to determine the nucleotide sequence similarity among Gluconobacter strains by using a $\mathrm{S} 1$ nuclease procedure.

\section{MATERIALS AND METHODS}

Bacterial strains. The strains used in the homology experiments and their sources are listed in Table 1. Escherichia coli strain B was included in all experiments as a nonhomologous control.

Purity of strains. Prior to use, each strain listed in Table 1 was streaked onto media adjusted to $\mathrm{pH} 6.0$ with $\mathrm{HCl}$ and containing $5 \%$ sorbitol, $1 \%$ yeast extract, $1 \%$ peptone, and $1.5 \%$ agar (5\% sorbitol agar); this was followed by incubation at $28^{\circ} \mathrm{C}$ for $48 \mathrm{~h}$. Colonies were examined with a dissecting microscope for heterogeneity. If more than one colony type was observed, each type was purified by repeated streakings onto 5\% sorbitol agar and designated by placing a lowercase letter after the strain number.

Phenotypic tests. All strains were tested for their ability to oxidize ethanol or lactate to $\mathrm{CO}_{2}$ and water (33) and for their ability to grow on $10 \%$ glucose agar adjusted to $\mathrm{pH} 4.5$ with acetic acid (16).

Culture maintenance. Stock cultures were maintained in $15 \%$ glycerol under liquid nitrogen. Working cultures were maintained as unfrozen suspensions in $6 \mathrm{M}$ sorbitol at $-15^{\circ} \mathrm{C}$ (37).

Culture preparation. Subcultures were grown in $50 \mathrm{ml}$ of sorbitol broth $(5 \%$ sorbitol, $1 \%$ yeast extract, and $1 \%$ peptone broth, pH 6.0) in 500-ml Bellco nephelometer flasks (37); these preparations were incubated at $28^{\circ} \mathrm{C}$ and shaken at $400 \mathrm{rpm}$ in a New Brunswick Rotary PsychroTherm incubator. After it reached maximum optical density (in most cases $1.0 \mathrm{U}$ of optical density at $620 \mathrm{~nm}$ ), the entire $50-\mathrm{ml}$ subculture was inoculated into a 2-liter Erlenmeyer flask containing $500 \mathrm{ml}$ of sorbitol broth and incubated as described above. Usually, 1,500 $\mathrm{ml}$ of culture was prepared for each deoxyribonucleic acid (DNA) isolation. Growth 
TABLE 1. Strains unsed in DNA-DNA homology studies of the genus Gluconobacter

\begin{tabular}{|c|c|c|c|}
\hline Name as received & $\begin{array}{l}\text { Culture } \\
\text { collec- } \\
\text { tion }^{a}\end{array}$ & Strain $^{b}$ & Other designation and/or comments \\
\hline "Acetobacter aurantium" & IFO & IFO $3245^{\text {Td }}$ & Type species of Frateuria aurantia $(35)^{e}$ \\
\hline "Acetobacter gluconicus" & $\begin{array}{l}\text { UQM } \\
\text { IFO }\end{array}$ & $\begin{array}{l}\text { UQM } 15 \\
\text { IFO } 3286^{\text {Td }}\end{array}$ & Two colony types $f$ \\
\hline \multirow[t]{2}{*}{ "Acetobacter industrius" } & ATCC & ATCC 12302 & IFO $3260^{g}$ \\
\hline & IFO & IFO $3261^{d}$ & Two colony types, both Gluconobacter \\
\hline "Acetobacter melanogenus" & ATCC & $\mathrm{ATCC} 9937^{d}$ & \\
\hline "Acetobacter melanogenum" & NRRL & NRRL B58 & \\
\hline "Acetobacter oxydans" & ATCC & ATCC $19357^{\text {Td }}$ & $\begin{array}{l}\text { Type species of G. oxydans (34); NCIB } \\
9013^{\text {Tg }}\end{array}$ \\
\hline \multirow[t]{2}{*}{ "Acetobacter rancens" } & ATCC & ATCC $23760^{d}$ & Acetobacter \\
\hline & IFO & IFO $3297^{d}$ & Two colony types, both Gluconobacter \\
\hline "Acetobacter roseus" & ATCC & ATCC 15180 & \\
\hline "Acetoacter species" & $\begin{array}{l}\text { CSIRO } \\
\text { CSIRO }\end{array}$ & $\begin{array}{l}\text { CSIRO B1506 } \\
\text { CSIRO B1507 }\end{array}$ & \\
\hline "Acetobacter suboxydans" & ATCC & ATCC 621 & $\mathrm{NCIB} 621^{g}$ \\
\hline $\begin{array}{l}\text { "Acetobacter suboxydans subsp. } \\
\text { hoyerium" }\end{array}$ & $\mathrm{C}$ & C $115 \mathrm{C}$ & \\
\hline "Acetobacter viscosus", & ATCC & ATCC $11895^{d}$ & NCIB $8131^{g}$ \\
\hline "Acetobacter xylinium", & CIP & CIP $5714^{d}$ & \\
\hline "Gluconobacter albius" & $\begin{array}{l}\text { IFO } \\
\text { IFO }\end{array}$ & $\begin{array}{l}\text { IFO } 3250^{d} \\
\text { IFO } 3251^{d}\end{array}$ & \\
\hline "Gluconobacter capsulatus" & NRRL & NRRL B1225 & \\
\hline \multirow[t]{5}{*}{ "Gluconobacter cerinus" } & ATCC & ATCC 19441 & IFO $3267^{g}$ \\
\hline & IFO & IFO $3264^{d}$ & \\
\hline & IFO & IFO $3265^{d}$ & \\
\hline & IFO & IFO $3268^{d}$ & Acetobacter \\
\hline & IFO & IFO $3270^{d}$ & \\
\hline \multirow{2}{*}{ "Gluconobacter dioxyacetonicus" } & IFO & IFO $3271^{d}$ & \\
\hline & IFO & IFO $3272^{d}$ & \\
\hline "Gluconobacter liquifaciens" & ATCC & ATCC $14835^{\mathrm{T} d}$ & $\begin{array}{l}\text { IAM } 1834^{\mathrm{T}} ; \text { Acetobacter liquefaciens } \\
\text { (15) }\end{array}$ \\
\hline \multirow{2}{*}{ "Gluconobacter melanogenum", } & IFO & IFO $3294^{d}$ & \\
\hline & IFO & IFO $3293^{d}$ & \\
\hline \multirow{2}{*}{ "Gluconobacter nonoxygluconicus" } & IFO & IFO 3275 & \\
\hline & IFO & IFO 3276 & Two colony types, both Gluconobacter \\
\hline \multirow[t]{9}{*}{ "G. oxydans" } & ATCC & ATCC $23651^{d}$ & $\begin{array}{l}\text { Two colony types, both Gluconobacter; } \\
\text { NCIB } 9014^{g}\end{array}$ \\
\hline & ATCC & ATCC $23652^{d}$ & NCIB $9119^{\circ}$ \\
\hline & ATCC & ATCC 23771 & NCIB $3734^{x}$ \\
\hline & ATCC & ATCC 23772 & Acetobacter; NCIB $5595^{g}$ \\
\hline & ATCC & ATCC 23775 & Acetobacter; NCIB $8624^{g}$ \\
\hline & RS & RS 137 & $?$ \\
\hline & RS & RS 149 & $?$ \\
\hline & RS & RS 203 & Possiblity of two colony types \\
\hline & RS & RS 303D & \\
\hline G. oxydans subsp. industrius & ATCC & ATCC $33446^{\mathrm{T}}$ & $\begin{array}{l}\text { LMD } 24.1^{\mathrm{T}} ; \text { two colony types, both } \\
\text { Gluconobacter }\end{array}$ \\
\hline \multirow{4}{*}{$\begin{array}{l}\text { G. oxydans subsp. melanogenus } \\
\text { G. oxydans subsp. suboxydans } \\
\text { "Gluconobacter roseus" }\end{array}$} & ATCC & ATCC $33447^{\mathrm{T}}$ & LMD $29.2^{\mathrm{T}}$ \\
\hline & ATCC & ATCC $33448^{\mathrm{T}}$ & $\operatorname{LMD} 23.2^{\mathrm{T}}$ \\
\hline & ATCC & ATCC 14960 & NCIB $9137^{g}$ \\
\hline & ATCC & ATCC 15178 & \\
\hline \multirow{2}{*}{$\begin{array}{l}\text { "Gluconobacter rubiginosis", } \\
\text { "Gluconobacter sphaericus" }\end{array}$} & IFO & IFO $3244^{d}$ & \\
\hline & IFO & IFO $12467^{\mathrm{T}}$ & G. oxydans subsp. sphaericus (34) \\
\hline \multirow{2}{*}{ "Gluconobacter suboxydans" } & ATCC & ATCC $621 \mathrm{H}$ & NCIB $8036^{x}$ \\
\hline & $\begin{array}{l}\text { IFO } \\
\text { IFO }\end{array}$ & $\begin{array}{l}\text { IFO } 12528^{d} \\
\text { IFO } 3254^{d}\end{array}$ & \\
\hline \multirow{3}{*}{$\begin{array}{l}\text { "Gluconobacter suboxydans var. al- } \\
\text { pha" } \\
\text { P'seudomonas diminuta } \\
\text { Pseudomonas vesiculare }\end{array}$} & & & \\
\hline & ATCC & ATCC $11568^{\mathrm{T}}$ & Two colony types, both purified \\
\hline & ATCC & ATCC $11426^{\mathrm{T}}$ & \\
\hline \multicolumn{4}{|c|}{$\begin{array}{l}{ }^{a} \text { ATCC, American Type Culture Collection, Rockville, Md.; C, Guinness (Dublin) Culture Collection, Dublin, Ireland; CIP, Collection de l'Institut Pasteur, } \\
\text { Paris, France; CSIRO, Division of Food Resources, Commonwealth Scientific and Industrial Research Organization, Ryde, Australia; IFO. Culture Collection of } \\
\text { the Institute of Fermentation, Osaka, Japan; IAM, Institute of Applied Microbiology, University of Tokyo, Tokyo, Japan; LMD, Laboratorium voor } \\
\text { Microbiologie der Landbouwhogeschool, Delft, The Netherlands; NCIB, National Collection of Industrial Bacteria, Aberdeen, Scotland, United Kingdom; } \\
\text { NRRL, Northern Regional Research Center, Peoria, Ill.; RS, pink pineapple disease strains obtained from K. G. Rohrbach, Department of Plant Pathology, } \\
\text { University of Hawaii at Manoa, Honolulu, Hawaii; UQM, Department of Microbiology, University of Queensiand Medical School, Queensland, Australia. } \\
{ }^{b} \text { Strains were received from the culture collections indicated unless otherwise noted. } \\
{ }^{c} \text { Genera were determined as described in the text. Unless otherwise noted, all strains phenotypically appeared to be Gluconobacter (Micales, M.S. thesis, } \\
\text { Virginia Polytechnic Institute and State University, Blacksburg, 1983).?, Inconclusive results with phenotypic tests for genus. } \\
d^{2} \text { Strain received from N.J. Palleroni, Hoffmann-La Roche Inc., Nutley, N.J. } \\
\text { e Numbers in parentheses are references. } \\
\text { S Strain UQM } 15 \text { a was an Acetobacter, and strain UQM } 15 \text { b was a Gluconobacter. } \\
\text { s Equivalent strain used by Gosselé et al. (20). }\end{array}$} \\
\hline
\end{tabular}


TABLE 2. Interrelatedness among the reference strains used in homology studies

\begin{tabular}{|c|c|c|c|c|c|c|c|c|c|c|c|}
\hline \multicolumn{2}{|c|}{ Unlabeled DNA from: } & \multicolumn{10}{|c|}{ \% Homology with labeled reference DNA from strain: ${ }^{a}$} \\
\hline Genus & Strain & $\begin{array}{l}\text { ATCC } \\
19357^{\mathrm{T}}\end{array}$ & $\begin{array}{l}\text { ATCC } \\
33447^{\mathrm{T}}\end{array}$ & $\begin{array}{l}\text { ATCC } \\
33448^{\mathrm{T}}\end{array}$ & $\begin{array}{c}\text { IFO } \\
12467^{\mathrm{T}}\end{array}$ & $\begin{array}{l}\text { IFO } \\
3264\end{array}$ & $\begin{array}{c}\text { IFO } \\
3276 a\end{array}$ & RS 149 & $\begin{array}{l}\text { ATCC } \\
14835^{\mathrm{T}}\end{array}$ & $\begin{array}{c}\text { IFO } \\
3245^{\mathrm{T}}\end{array}$ & $\begin{array}{l}\text { ATCC } \\
11426^{\mathrm{T}}\end{array}$ \\
\hline \multirow[t]{6}{*}{ Gluconobacter } & ATCC $19357^{\mathrm{T}}$ & 100 & 76 & 90 & 77 & 18 & 14 & 4 & 2 & 4 & 7 \\
\hline & $\operatorname{ATCC} 33447^{\mathrm{T}}$ & 83 & 100 & 78 & 67 & 10 & 14 & 2 & 7 & 1 & 2 \\
\hline & ATCC $33448^{\mathrm{T}}$ & 94 & 78 & 100 & 80 & 11 & 12 & 2 & 8 & 2 & 3 \\
\hline & IFO $12467^{\mathrm{T}}$ & 65 & 59 & 61 & 100 & 12 & 11 & 3 & 3 & 2 & 1 \\
\hline & IFO 3264 & 21 & 19 & 19 & 15 & 100 & 30 & 1 & 0 & 4 & 1 \\
\hline & IFO 3276a & 14 & 12 & 14 & 10 & 24 & 100 & 2 & 0 & 3 & 1 \\
\hline Unknown & RS 149 & 4 & 6 & 8 & 4 & 2 & 5 & 100 & 1 & 0 & 3 \\
\hline Acetobacter & ATCC $14835^{\mathrm{T}}$ & 10 & 10 & 12 & 8 & 1 & 1 & 4 & 100 & 2 & 2 \\
\hline Frateuria & IFO $3245^{\mathrm{T}}$ & 3 & 5 & 4 & 2 & 5 & 0 & 2 & 2 & 100 & 3 \\
\hline Pseudomonas & ATCC $11426^{\mathrm{T}}$ & 5 & 7 & 7 & 9 & 2 & 0 & $\overline{4}$ & 2 & 0 & 100 \\
\hline
\end{tabular}

${ }^{a}$ All homology values (expressed as percentages of the homologous control) except those obtained with labeled DNA from strain ATCC $11426^{\mathrm{T}}$ were based on an average of two or more determinations from the same preparation; the values obtained with labeled DNA from strain ATCC $11426^{\mathrm{T}}$ were based on one determination. The Gluconobacter strains used to delimit homology group I were strains ATCC $19357^{\mathrm{T}}$, ATCC $33447^{\mathrm{T}}$ ATCC $33448^{\mathrm{T}}$, and IFO $12467^{\mathrm{T}}$, and the strains used to delimit homology groups II and III were strains IFO 3264 and IFO $3276 \mathrm{a}$, respectively.

was followed on undiluted cultures by using a Bausch \& Lomb Spectronic 20 spectrophotometer and a $14-\mathrm{mm}$ light path length. Cultures were harvested at $0.8 \mathrm{U}$ of optical density at $620 \mathrm{~nm}$ by centrifugation at $16,300 \times \mathrm{g}$ for $15 \mathrm{~min}$.

DNA isolation and purification. Cells were suspended in 30 $\mathrm{ml}$ of distilled water, and $1.5 \mathrm{ml}$ of $3 \mathrm{M} \mathrm{NaCl}-0.2 \mathrm{M}$ ethylenediaminetetraacetate $(\mathrm{pH} 8.0)$ was added to this suspension. The $\mathrm{pH}$ was adjusted to 9.0 with $3 \mathrm{M} \mathrm{NaOH}$, and this was followed by the addition of $0.5 \mathrm{ml}$ of a solution containing $250 \mathrm{U}$ of ribonuclease $\mathrm{T}_{1}$ per $\mathrm{ml}$ and $0.75 \mathrm{ml}$ of a solution containing $0.5 \mathrm{mg}$ of ribonuclease A per ml. Cell walls were partially digested by adding $1 \mathrm{ml}$ of a solution containing $7.5 \mathrm{mg}$ of lysozyme per $\mathrm{ml}$ in $0.1 \mathrm{M}$ tris(hydroxymethyl)aminomethane buffer ( $\mathrm{pH} 9.2$ ), followed by shaking for $30 \mathrm{~min}$ at room temperature. Lysis was completed by adding $1.5 \mathrm{ml}$ of a $20 \%$ sodium dodecyl sulfate solution.

DNA was isolated from bacterial lysates by using a modification of the hydroxylapatite (HA) method described by Johnson (24). After phenol extraction, the cell lysate was dialyzed against a $0.15 \mathrm{M} \mathrm{NaCl}-0.01 \mathrm{M}$ ethylenediaminetetraacetate solution for $2 \mathrm{~h}$ before additional ribonuclease was added to the lysate. After ethanol precipitation and redissolving of the DNA, an additional chloroform extraction step was included; $0.015 \mathrm{M} \mathrm{NaCl}-0.0015 \mathrm{M}$ trisodium citrate $(\mathrm{pH}$ 7.0) was used for all subsequent dialysis and for DNA storage. The HA was prepared by the method of Lachance (26). Prior to use, the HA was boiled in $0.1 \mathrm{M}$ phosphate buffer for 2 to $3 \mathrm{~min}$. The amount of HA was then adjusted to $6 \mathrm{~g}$ (wet weight) of HA per $15 \mathrm{ml}$ of HA suspension.

Thermal melting point and purity determinations. The thermal melting points and purities of the isolated DNAs were determined spectrophotometrically $(24,28)$. The guanine-plus-cytosine $(\mathrm{G}+\mathrm{C})$ contents were determined from thermal melting point values by using the formula of Mandel et al. (28). Escherichia coli strain B was used as a $\mathrm{G}+\mathrm{C}$ standard (24). DNA purity was calculated by the method of Johnson (24).

Iodination of reference strain DNA. DNA was labeled with ${ }^{125}$ I by using the method of Selin et al. (32). The average specific activity obtained with this procedure was $1.9 \times 10^{6}$ $\mathrm{cpm} / \mu \mathrm{g}$ of DNA. Only DNA preparations that were more than $80 \%$ pure were used for reference DNA labeling.

DNA homology experiments. DNA homology values were determined with the free solution $\mathrm{S} 1$ nuclease procedure described by Johnson (24). The reassociation mixtures con- sisted of $50 \mu \mathrm{l}$ of unlabeled denatured DNA $(0.6 \mathrm{mg} / \mathrm{ml}), 50$ $\mu \mathrm{l}$ of $0.88 \mathrm{M} \mathrm{NaCl}-10^{-3} \mathrm{M}$ HEPES ( $N$-2-hydroxyethylpiperazine- $N^{\prime}$-2-ethanesulfonic acid) buffer, and $10 \mu \mathrm{l}$ of labeled denatured DNA and were incubated for $24 \mathrm{~h}$ at $68.6^{\circ} \mathrm{C}$. Nuclease-resistant duplexes were precipitated as previously described (24), except that $0.5 \mathrm{ml}$ of a $1 \mathrm{~N} \mathrm{HCl}$ solution containing $1 \% \mathrm{NaH}_{2} \mathrm{PO}_{4}$ and $1 \% \mathrm{Na}_{4} \mathrm{P}_{2} \mathrm{O}_{7}$ (29) was used. The DNA precipitates were collected on Whatman GF/F glass fiber filter strips by using a 1:4 dilution of the acid solution and dried under a heat lamp for $1 \mathrm{~h}$, and the radioactivity was measured with a Beckman model 5500 gamma counter.

\section{RESULTS}

The levels of purity of the DNA preparations used in this study ranged from 59 to $99 \%$ (average, $77 \%$ ).

Reciprocal homology values for the reference strains used in this study are shown in Table 2. The levels of homology among the type strains of four of the five $G$. oxydans subspecies (34) ranged from 59 to $94 \%$. Reference strains representing two additional groups of Gluconobacter (strains IFO 3264 and IFO 3276a) had levels of homology with the $G$. oxydans strains that ranged from 10 to $21 \%$. The remaining reference strains in Table 2 represent genera that are phenotypically similar to Gluconobacter; these strains had levels of homology of $\leq 10 \%$ with the Gluconobacter strains.

DNA preparations from 59 organisms were compared with the reference organisms; 32 of these strains were placed in homology group I and had $\mathrm{G}+\mathrm{C}$ contents that ranged from 54 to $59 \mathrm{~mol} \%$ (Table 3). These strains had 34 to $99 \%$ homology with the four Gluconobacter type strains. Compared with the type species (strain ATCC $19357^{\mathrm{T}}[\mathrm{T}=$ type strain]), 27 strains had levels of homology that were greater than $60 \%$ (average, $86 \%$ ). Three of the remaining four strains demonstrated more than $50 \%$ homology with the type species, G. oxydans (strain ATCC $19357^{\mathrm{T}}$ ).

Homology group II consisted of 12 strains which had $\mathrm{G}+\mathrm{C}$ contents that ranged from 53 to $55 \mathrm{~mol} \%$ (Table 4). Compared with reference strain IFO 3264, the levels of homology ranged from 44 to $87 \%$ (average, $65 \%$ ).

Six strains belonged to homology group III, which was delineated with reference strain IFO 3276 a (Table 4). The $\mathrm{G}+\mathrm{C}$ contents ranged from 52 to $55 \mathrm{~mol} \%$. Strain IFO $3276 \mathrm{~b}$ had $99 \%$ homology with strain IFO 3276a; thus, we concluded that these two isolates were colony variants of the same strain. The levels of homology with the five remaining 
TABLE 3. Homology group I: DNA homology values of strains having high levels of homology with Gluconobacter type strains

\begin{tabular}{|c|c|c|c|c|c|}
\hline \multirow{2}{*}{$\begin{array}{c}\text { Source of } \\
\text { unlabeled DNA }\end{array}$} & \multirow{2}{*}{$\begin{array}{l}\mathrm{G}+\mathrm{C} \\
\text { content } \\
\text { (mol\%) }\end{array}$} & \multicolumn{4}{|c|}{$\begin{array}{l}\% \text { Homology with labeled reference DNA } \\
\text { from strain: }\end{array}$} \\
\hline & & $\begin{array}{l}\text { ATCC } \\
19357^{\mathrm{T}}\end{array}$ & $\begin{array}{l}\text { ATCC } \\
33447^{\mathrm{T}}\end{array}$ & $\begin{array}{l}\text { ATCC } \\
33448^{\mathrm{T}}\end{array}$ & $\begin{array}{c}\text { IFO } \\
12467^{\mathrm{T}}\end{array}$ \\
\hline ATCC $19357^{\mathrm{T}}$ & 59 & 100 & 76 & 90 & 77 \\
\hline NRRL B1225 & $\mathrm{ND}^{a}$ & 99 & 76 & 92 & 75 \\
\hline ATCC 11895 & ND & 96 & 73 & 90 & 76 \\
\hline IFO 12528 & ND & 95 & 76 & 94 & 72 \\
\hline ATCC $621 \mathrm{H}$ & ND & 94 & 76 & 92 & 77 \\
\hline ATCC $33448^{\mathrm{T}}$ & 59 & 94 & 78 & 100 & 80 \\
\hline C $115 \mathrm{C}$ & ND & 93 & 75 & 86 & 74 \\
\hline CIP 5714 & ND & 93 & 76 & 92 & 72 \\
\hline ATCC 23652 & ND & 92 & 76 & 100 & 79 \\
\hline ATCC $33446^{\mathrm{T}}$ & 59 & 92 & 74 & 87 & 83 \\
\hline ATCC $33446 a^{b}$ & 57 & 80 & 76 & 87 & 72 \\
\hline ATCC $33446 \mathrm{~b}$ & 59 & 87 & 77 & 85 & 79 \\
\hline IFO $3261 a^{c}$ & 59 & 92 & 79 & 93 & 70 \\
\hline ATCC 621 & ND & 91 & 73 & 89 & 82 \\
\hline ATCC 23771 & 55 & 90 & 74 & 94 & 69 \\
\hline CSIRO B1506 & ND & 87 & 90 & 83 & 73 \\
\hline IFO 3244 & ND & 86 & 80 & 83 & 62 \\
\hline ATCC 9937 & ND & 85 & 75 & 82 & 75 \\
\hline IFO 3294 & ND & 85 & 81 & 83 & 67 \\
\hline ATCC $33447^{\mathrm{T}}$ & 56 & 83 & 100 & 78 & 67 \\
\hline CSIRO B 1507 & ND & 83 & 82 & 82 & 70 \\
\hline IFO 3293 & ND & 83 & 84 & 83 & 52 \\
\hline IFO $3297 b^{c}$ & 58 & 83 & 82 & 82 & 70 \\
\hline ATCC 23760 & ND & 81 & 77 & 79 & 70 \\
\hline ATCC 23772 & ND & 81 & 71 & 81 & 65 \\
\hline NRRL 58 & ND & 76 & 75 & 75 & 67 \\
\hline IFO 12467 & 57 & 65 & 59 & 61 & 100 \\
\hline ATCC 14960 & 56 & 61 & 57 & 54 & 54 \\
\hline IFO 3250 & 59 & 53 & 46 & 48 & 52 \\
\hline ATCC 2365la & 57 & 51 & 38 & 53 & 41 \\
\hline ATCC $23651 b$ & 57 & 52 & 40 & 49 & 40 \\
\hline IFO $3275 a^{c}$ & 54 & 42 & 39 & 41 & 34 \\
\hline
\end{tabular}

a ND, Not determined.

${ }^{b}$ Lowercase letters after a strain number indicate different colony types isolated from the original strain.

'Strain having two colony types which are in separate homology groups.

strains in homology group III ranged from 71 to $99 \%$ (average, 86\%).

Table 5 shows results for four additional strains exhibiting phenotypic properties (Table 1) of acetic acid bacteria (7, 11). Strains ATCC 19441 and ATCC 23775 had significant levels of homology (19 and 20\%) with the type species, $G$. oxydans (strain ATCC $19357^{\mathrm{T}}$ ), whereas strains IFO 3261b and UQM $15 b$ showed about $10 \%$ homology with the type species (Table 5).

Strains RS 137, RS 149, and RS 303D reportedly cause pink disease of pineapples (K. G. Rohrbach, personal communication). The $\mathrm{G}+\mathrm{C}$ contents of these strains ranged from 50 to $53 \mathrm{~mol} \%$ (Table 5). These three Rohrbach strains showed a high degree of homology $(>90 \%)$ with strain RS 149 (Table 5). In addition, strain RS 303D had significant levels of homology with strains IFO 3264 and IFO 3276a (Table 5).

\section{DISCUSSION}

Differentiation of Gluconobacter from other genera. De Ley et al. (13) placed Gluconobacter and Acetobacter in the family Acetobacteraceae. These two genera are commonly referred to as the acetic acid bacteria, and they are composed of gram-negative or gram-variable, ellipsoidal to rodshaped cells that (i) have a strictly respiratory type of metabolism with oxygen as the terminal electron acceptor, (ii) are oxidase negative, (iii) oxidize ethanol to acetic acid, (iv) grow in acidic media, and ( $v$ ) are found in sugary and alcoholized, slightly acid niches, such as fruits, flowers, fermented plant juices, and honey. Primary phenotypic differentiation between these two genera depends upon the fact that the acetobacters have a functional tricarboxylic acid cycle (15) and the gluconobacters do not (14). The presence or absence of a functional tricarboxylic acid cycle is determined by a test that shows complete oxidation of ethanol or lactate to $\mathrm{CO}_{2}$ and water during growth on solid media (16).

The genus Frateuria resembles Gluconobacter in a number of respects, most notably in its ability to oxidize ethanol to acetic acid and grow under acidic conditions (35). Unlike the gluconobacters, however, the frateurias completely oxidize lactate to $\mathrm{CO}_{2}$ and water, produce $\mathrm{H}_{2} \mathrm{~S}$, and grow in the absence of vitamins (35).

Isolation and characterization of gluconobacters commonly involves growth on an acidic medium $(9,14)$, but the recent literature does not indicate which acid should be used to lower the $\mathrm{pH}$ of the isolation medium. In 1950, Frateur (16) recommended acidifying isolation media with acetic acid and then culturing the bacteria on a medium containing $10 \%$ sugar. We have found that a medium containing $10 \%$ glucose, $1 \%$ yeast extract, and $1 \%$ peptone works well for isolating and growing acetic acid bacteria when acetic acid is used to adjust the $\mathrm{pH}$ to 4.5 (C. A. Baker and G. W. Claus, unpublished data). However, we also have found that many other bacteria, including $E$. coli, grow if $\mathrm{HCl}$ is used to acidify this medium instead of acetic acid (Micales, unpublished data). Our observations suggest that it is acetate anion tolerance, not just acidic conditions, that differentiates acetic acid bacteria and frateurias from other bacteria. We

TABLE 4. Homology groups II and III: strains having high levels of homology with Gluconobacter reference strains IFO 3264 and IFO $3276 \mathrm{a}$

\begin{tabular}{|c|c|c|c|}
\hline \multirow{2}{*}{$\begin{array}{c}\text { Source of unlabeled } \\
\text { DNA }\end{array}$} & \multirow{2}{*}{$\begin{array}{c}\mathrm{G}+\mathrm{C} \\
\text { content } \\
(\mathrm{mol} \%)\end{array}$} & \multicolumn{2}{|c|}{$\begin{array}{l}\text { \% Homology with la- } \\
\text { beled reference DNA } \\
\text { from strain: }\end{array}$} \\
\hline & & $\begin{array}{l}\text { IFO } \\
3264\end{array}$ & $\begin{array}{c}\text { IFO } \\
3276 \mathrm{a}^{\prime \prime}\end{array}$ \\
\hline \multicolumn{4}{|l|}{ Homology group II } \\
\hline IFO 3264 & 55 & 100 & 30 \\
\hline IFO 3272 & 55 & 87 & 32 \\
\hline IFO 3271 & 55 & 77 & 26 \\
\hline UQM $15 \mathrm{a}^{b}$ & 53 & 75 & 23 \\
\hline ATCC 12302 & 55 & 70 & 24 \\
\hline ATCC 15178 & 55 & 68 & 25 \\
\hline IFO 3270 & 55 & 64 & 29 \\
\hline ATCC 15180 & 55 & 62 & 24 \\
\hline IFO 3251 & 55 & 59 & $\mathrm{ND}^{\prime}$ \\
\hline IFO 3286 & 55 & 58 & 35 \\
\hline IFO 3268 & 54 & 54 & 25 \\
\hline IFO 3254 & 55 & 44 & 20 \\
\hline \multicolumn{4}{|l|}{ Homology group III } \\
\hline IFO $3276 a$ & 54 & 22 & 100 \\
\hline IFO $3276 \mathrm{~b}$ & 54 & 23 & 99 \\
\hline IFO 3265 & 55 & 65 & 99 \\
\hline IFO $3275 b^{b}$ & 52 & 67 & 97 \\
\hline IFO $3297 a^{b}$ & 54 & 21 & 77 \\
\hline RS 203b & 53 & 19 & 71 \\
\hline
\end{tabular}

"Lowercase letters after a strain number indicate different colony types isolated from the original strain.

${ }^{b}$ Strain having two colony types which are in separate homology groups. ND, Not determined. 
TABLE 5. DNA homology values for other acetic acid bacteria and Rohrbach strains

\begin{tabular}{|c|c|c|c|c|c|c|c|c|c|c|c|}
\hline \multirow{2}{*}{$\begin{array}{c}\text { Source of } \\
\text { unlabeled } \\
\text { DNA }\end{array}$} & \multirow{2}{*}{$\begin{array}{c}\mathrm{G}+\mathrm{C} \\
\text { content } \\
(\mathrm{mol} \%)\end{array}$} & \multicolumn{10}{|c|}{$\%$ Homology with labeled reference DNA from strain:" } \\
\hline & & $\begin{array}{l}\text { ATCC } \\
19357^{\mathrm{T}}\end{array}$ & $\begin{array}{l}\text { ATCC } \\
33447^{\mathrm{T}}\end{array}$ & $\begin{array}{l}\text { ATCC } \\
33448^{\mathrm{T}}\end{array}$ & $\begin{array}{c}\text { IFO } \\
12467^{\mathrm{T}}\end{array}$ & $\begin{array}{l}\text { IFO } \\
3264\end{array}$ & $\begin{array}{c}\text { IFO } \\
3276 \mathrm{a}^{b}\end{array}$ & $\begin{array}{l}\text { RS } \\
149\end{array}$ & $\begin{array}{l}\text { ATCC } \\
14835^{\mathrm{T}}\end{array}$ & $\begin{array}{c}\mathrm{IFO} \\
3245^{\mathrm{T}}\end{array}$ & $\begin{array}{l}\text { ATCC } \\
11426^{\mathrm{T}}\end{array}$ \\
\hline ATCC 19441 & 55 & 20 & 17 & 21 & 14 & 23 & $\mathrm{ND}^{c}$ & ND & 0 & 0 & ND \\
\hline ATCC 23775 & 55 & 19 & 18 & 19 & 17 & 11 & ND & ND & 3 & 4 & ND \\
\hline IFO $3261 b^{d t}$ & 59 & 10 & 11 & 13 & 6 & 0 & 0 & 2 & 2 & 0 & 0 \\
\hline UQM $15 b^{d}$ & 53 & 10 & 10 & 9 & 14 & 0 & 3 & 3 & 0 & 1 & 2 \\
\hline $\operatorname{RS} 137^{e}$ & 51 & 7 & 9 & 9 & 11 & ND & ND & 92 & 1 & 1 & ND \\
\hline $\mathrm{RS} 149^{\circ}$ & 50 & 4 & 6 & 8 & 4 & 2 & 5 & 100 & 1 & 0 & 3 \\
\hline RS 303D ${ }^{e}$ & 51 & 20 & 21 & 21 & 22 & 41 & 68 & 93 & 2 & 4 & 1 \\
\hline
\end{tabular}

"All homology values except those obtained with labeled DNA from strain ATCC $11426^{\mathrm{T}}$ were based on an average of two or more determinations from the same preparation; the values obtained with labeled DNA from strain ATCC $11426^{\mathrm{T}}$ were based on one determination.

${ }^{b}$ Lowercase letters after a strain number indicate different colony types isolated from the original strain.

'ND, Not determined.

${ }^{d}$ Strain having two colony types which are in separate homology groups.

' Rohrbach strains RS 137, RS 149, and RS 303D reportedly cause pink disease of pineapples. These strains phenotypically did not appear to be acetic acid bacteria, nor did they fit well into any of the Gluconobacter homology groups.

suspect that some workers have failed to use acetic acid to lower the $\mathrm{pH}$ of isolation media and that this has contributed to the misidentification of certain gram-negative, aerobic, rod-shaped isolates as acetic acid bacteria.

Subgeneric status. Recent phenotypic studies $(8,11,12$, $14,19,20,27)$ suggest that the genus Gluconobacter should be composed of one species, $G$. oxydans. Although unpublished DNA homology results of Gillis (20) indicate genetic heterogeneity among $G$. oxydans strains, our more comprehensive study shows three distinct homology groups within this genus (Tables 3 and 4 ) with an average intergroup DNA homology level of $16 \%$ (Table 2). Considering the proposal of Johnson (24) coupled with the procedures correlation study by Grimont et al. (22), our data support the proposal that each Gluconobacter homology group be considered a separate species. Since the type strain of $G$. oxydans is in homology group I, we presently regard all homology group I strains as $G$. oxydans. We also regard homology groups II and III as separate, but as yet unnamed, species of Gluconobacter.

The recent phenotypic studies cited in the preceding paragraph suggest that subspecies designations within this genus be eliminated. Our data also support this elimination, since all type strains belonged to the same homology group (Table 2). We recognize a certain degree of heterogeneity within these three homology groups, but we do not recommend additional subgrouping at this time because of the small number of strains tested and a lack of obvious phenotypic differences.

Comparison with previous numerical taxonomy data. Gosselé et al. (20) used phenotypic tests and gel electrophoresis to examine 98 Gluconobacter strains, and they concluded that Gluconobacter contains one species, G. oxydans, which should not be divided into subspecies. These authors found some variation within the genus, which grouped their strains into two phena; phenon B strains required nicotinic acid, and phenon A strains did not. They also observed slight differences in protein electrophoresis patterns.

In the present study we included 29 of the strains examined by Gosselé et al. (20). All 15 of the phenon B strains were in our homology group I (Table 6). Of the 14 phenon A strains, 1 was in homology group I, 9 were in homology group II, and 2 each were in homology group III and the unidentified group. Since all but one of the 16 homology group I strains ( $G$. oxydans) used in both studies belonged to phenon $B$, it appears that the requirement for nicotinic acid is a valuable characteristic for differentiating this species from other gluconobacters.

Rohrbach strains. Bacterial pink disease of pineapple fruit is a condition previously attributed to certain strains of Gluconobacter oxydans $(30,31)$, such as strains RS $137, \mathrm{RS}$ 149, RS 203, and RS 303D (K. G. Rohrback, personal

TABLE 6. Comparison of DNA homology groups from the present study and phena described by Gosselé et al.

\begin{tabular}{|c|c|c|}
\hline $\begin{array}{l}\text { Homology } \\
\text { group }^{a}\end{array}$ & Strain $^{b}$ & $\begin{array}{c}\text { Phenon of } \\
\text { Gosselé } \\
\text { et al.c }\end{array}$ \\
\hline \multirow[t]{16}{*}{ I } & ATCC 621 & B \\
\hline & ATCC $621 \mathrm{H}$ & B \\
\hline & ATCC 11895 & B \\
\hline & ATCC 14960 & B \\
\hline & ATCC 19357 & B \\
\hline & ATCC $23651 a, b$ & B \\
\hline & ATCC 23652 & B \\
\hline & ATCC 23771 & B \\
\hline & ATCC 23772 & B \\
\hline & ATCC $33446 a, b$ & B \\
\hline & ATCC 33447 & B \\
\hline & IFO 3244 & B \\
\hline & IFO 3293 & B \\
\hline & IFO 3294 & A \\
\hline & IFO 12467 & B \\
\hline & IFO 12528 & B \\
\hline \multirow[t]{9}{*}{ II } & ATCC 12302 & A \\
\hline & ATCC 15178 & A \\
\hline & ATCC 15180 & A \\
\hline & IFO 3251 & A \\
\hline & IFO 3264 & A \\
\hline & IFO 3268 & A \\
\hline & IFO 3270 & A \\
\hline & IFO 3271 & A \\
\hline & IFO 3286 & A \\
\hline \multirow[t]{2}{*}{ III } & IFO 3265 & A \\
\hline & IFO 3276a,b & A \\
\hline \multirow[t]{2}{*}{ Unidentified } & ATCC 19441 & A \\
\hline & ATCC 23775 & A \\
\hline
\end{tabular}

"The homology groups are those shown in Tables 3 and 4 . Levels of homology of unidentified strains are shown in Table 5.

${ }^{b}$ The strains used in this study are the same as those used by Gosselé et al. (20) according to the information in culture collection catalogs. Lowercase letters after strain numbers indicate colony types isolated during this investigation.

See reference 20 . 
communication). However, our DNA homology studies showed that only strain RS $203 \mathrm{~b}$, one of two colony types isolated from the organism received as strain RS 203, was a Gluconobacter. Colony type RS 203b had $71 \%$ homology with the homology group III reference strain (Table 4), and it exhibited typical phenotypic characteristics of Gluconobacter. The other colony type, colony type RS 203a, was lost during storage.

Although the remaining Rohrbach strains (strains RS 137, RS 149 , and RS 303D) are closely related to each other, they do not appear to be strains of Gluconobacter, Acetobacter, or Frateuria, because they did not grow on $10 \%$ glucose agar at $\mathrm{pH} 4.5$ and they did not completely oxidize ethanol or lactate. Although strain RS 303D demonstrated only one colony type, our DNA homology values suggested that it was a mixed culture (Table 5). Strain RS 303D had 93\% homology with strain RS 149, 68\% homology with the homology group II indicator strain (IFO 3264), and 41\% homology with the homology group III indicator strain (IFO 3276a). This may explain why this strain was previously identified by others as a Gluconobacter species. Our results with the Rohrbach strains prompt us to caution others in attributing pineapple phytopathogenicity to the gluconobacters.

Colony variants and culture purity. Although most of the cultures used in this study were pure, some exhibited two or more stable colony types (Table 1). These were often difficult to detect without using a dissecting microscope. In some cases, separate colony types isolated from a single culture showed almost identical homology values when they were compared with reference strains (e.g., colony types ATCC 23651a and ATCC 23651b, ATCC 33446a and ATCC 33446b, and IFO 3276a and IFO 3276b) (Tables 3 and 4). With other cultures, however, separate colony types were found to be in different homology groups (e.g., colony types IFO 3261a and IFO 3261b, IFO 3275a and IFO 3275b, and IFO 3297a and IFO 3297b) (Tables 3 through 5).

Multiple colony types from other cultures did not give such clear-cut results. For example, strain IFO 3261 was found by ribosomal ribonucleic acid homology to be an Acetobacter (18). Similarly, T. Iijmia and K. Imai (Institute for Fermentation, Osaka, Japan, personal communication) found that this strain completely oxidizes lactate to $\mathrm{CO}_{2}$ and water, which also places it in the genus Acetobacter. We found that strain IFO 3261 had two colony types; colony type IFO 3261 a was a G. oxydans strain (homology group I); and colony type IFO 3261b phenotypically appeared to be a Gluconobacter (Table 1), but it had only low levels of homology with the $G$. oxydans reference strains (Table 5). Although our results do not support the hypothesis that strain IFO 3261 is an Acetobacter, the taxonomic position of colony type IFO $3261 \mathrm{~b}$ still is not clear.

Another interesting example was strain UQM 15. Phenotypically, colony type UQM 15a was an Acetobacter (Table 1); however, it had $75 \%$ homology with the Gluconobacter homology group II reference strain. Thus, colony type UQM 15 a appeared to be a phenotypically unusual Gluconobacter. Colony type UQM 15b, like colony type IFO 3261b, demonstrated typical Gluconobacter phenotypic characteristics and also showed about $10 \%$ homology with the $G$. oxydans reference strains (Table 5). Thus, colony types UQM $15 \mathrm{~b}$ and IFO $3261 \mathrm{~b}$ appear to be similar and may represent another Gluconobacter species.

On the other hand, mixed cultures may not always be evident by examining colony morphology. For example, strain IFO 3265 and colony type IFO 3275 b each contained only one colony type, yet each culture showed high levels of homology with both homology group II and homology group III strains (Table 4). Therefore, strain IFO 3265 and colony type IFO 3275 b may each be a mixture of two Gluconobacter species that exhibit identical colony types.

The reason(s) for the common occurrence of mixed cultures of acetic acid bacteria is not clear. Spontaneous mutation at a high frequency has been considered (10), but there seems to be little evidence to support this idea. We have observed that cells in Gluconobacter or Acetobacter cultures often stick tightly together in clumps of micro- or macroscopic size. This cell-to-cell adhesion appears to be influenced by both medium composition and growth phase. It seems likely that the ability of acetic acid bacteria to stick to one another causes problems in culture purification. For example, if cells from one type of Gluconobacter are present in very low numbers and are tightly stuck to clumps of a more predominant yet genetically different type, the presence of this minor colony type may not be detected on streak plates. However, if some physical or chemical change in the environment selectively causes the minor colony type to become more numerous, or if an environmental change causes clumps to be dispersed so that cells from the minor colony type are released, then different colony types might seem to appear spontaneously. This latter reasoning may explain why we recently recovered a mixture of two colony types from a culture whose purity was rigorously checked prior to storage for several years in liquid nitrogen.

We wonder whether undetected mixtures of acetic acid bacteria have caused other workers to describe strains that are "intermediate" between Gluconobacter and 'Acetobacter (7). It is also conceivable that shifts in proportions of different colony types may have been responsible for the phenotypic variations observed in some strains of acetic acid bacteria (6-8).

The tendency for cells to adhere to one another makes these cultures difficult to work with by using classical pure culture techniques. Our experience with cultures from other culture collections suggests that other workers may also be working with mixed colony types of acetic acid bacteria. To avoid continuance of this understandable problem, we recommend that investigators (i) use a dissecting microscope to examine many well-isolated colonies from a number of streak or spread plates before homogeneity is assumed, and (ii) prepare each new stock culture from a single, well-isolated colony. Although application of these procedures should reduce the number of mixed Gluconobacter cultures, it will not prevent investigators from working with different Gluconobacter species that have identical colony types. Perhaps a comparison of DNA homology with a reference strain of indisputable purity is the only reliable criterion that a Gluconobacter or Acetobacter culture is pure.

\section{ACKNOWLEDGMENTS}

This study was supported in part by a grant from the Bergey's Trust Fund. Financial support was provided for B.K.M. by a Graduate Assistantship from Virginia Polytechnic Institute and State University.

We thank R. Gherna of the American Type Culture Collection, Rockville, Md., and N. J. Palleroni of Hoffmann-La Roche, Inc., Nutley, N.J., for supplying the strains used in this study. We also gratefully acknowledge the following people: C. A. Baker for establishing and maintaining stock cultures in liquid nitrogen; T. Iijima and K. Imai of the Institute for Fermentation, Osaka, Japan, for supplying unpublished phenotypic data on strains; Ronald Manning and D. L. Pruess of Hoffman-La Roche, Inc., for discussions about 
colony variations among the acetic acid bacteria; and N. R. Krieg for his guidance and input during this study.

\section{LITERATURE CITED}

1. Ameyama, M. 1975. Gluconobacter oxydans subspecies sphaericus, new subspecies isolated from grapes. Int. J. Syst. Bacteriol. 23:365-370.

2. Asai, T. 1935. A systematic study of alcohol- and carbohydrateoxidizing bacteria isolated from fruits and a new classification of oxidizing bacteria III. Nippon Nogei Kagaku Kaishi 11:674-708.

3. Asai, T. 1935. A systematic study of alcohol- and carbohydrateoxidizing bacteria isolated from fruits and a new classification of oxidizing bacteria III. Nippon Nogei Kagaku Kaishi 11:610-620.

4. Asai, T. 1935. A systematic study of alcohol- and carbohydrateoxidizing bacteria isolated from fruits and a new classification of oxidizing bacteria III. Nippon Nogei Kagaku Kaishi 11:499-513.

5. Asai, T. 1935. A systematic study of alcohol- and carbohydrateoxidizing bacteria isolated from fruits and a new classification of oxidizing bacteria III. Nippon Nogei Kagaku Kaishi 11:377-390.

6. Asai, T. 1968. Acetic acid bacteria. University of Tokyo Press, Tokyo.

7. Asai, T., H. Iizuka, and K. Komagata. 1964. The flagellation and taxonomy of genera Gluconobacter and Acetobacter with reference to the existence of intermediate strains. J. Gen. Appl. Microbiol. 10:95-126.

8. Asai, T., and K. Shoda. 1958. The taxonomy of Acetobacter and allied oxidative bacteria. J. Gen. Appl. Microbiol. 4:289-311.

9. Carr, J. G., and S. M. Passmore. 1979. Methods for identifying acetic acid bacteria, p. 33-47. In F. A. Skinner and D. W. Lovelock (ed.), Identification methods for microbiologists, 2nd ed. Academic Press, Inc., London.

10. Carr, J. G., and J. L. Shimwell. 1961. The acetic acid bacteria, 1941-1961: a critical review. Antonie van Leeuwenhoek J. Microbiol. Serol. 27:386-400.

11. De Ley, J. 1961. Comparative carbohydrate metabolism and a proposal for the phylogenetic relationship of the acetic acid bacteria. J. Gen. Microbiol. 24:31-50.

12. De Ley, J., and J. Frateur. 1974. Gluconobacter Asai 1935, p. 251-253. In R. E. Buchanan and N. E. Gibbons (ed.), Bergey's manual of determinative bacteriology, 8th ed. The Williams \& Wilkins Co., Baltimore.

13. De Ley, J., M. Gillis, and J. Swings. 1984. Family VI. Acetobacteraceae Gillis and De Ley 1980 , p. 267-268. In N. R. Krieg (ed.), Bergey's manual of systematic bacteriology, vol. 1. The Williams \& Wilkins Co., Baltimore.

14. De Ley, J., and J. Swings. 1984. The genus Gluconobacter Asai 1935, emend. mut. char. Asai, Iizuka, and Komagata 1964, p. 275-278. In N. R. Krieg (ed.), Bergey's manual of systematic bacteriology, vol. 1. The Williams \& Wilkins Co., Baltimore.

15. De Ley, J., J. Swings, and F. Gosselé. 1984. Genus 1. Acetobacter Beijerinck 1898, 215, p. 268-274. In N. R. Krieg (ed.), Bergey's manual of systematic bacteriology, vol. 1. The Williams \& Wilkins Co., Baltimore.

16. Frateur, J. 1950. Essai sur la systématique des acetobacters. Cellule 53:287-392.

17. Fulmer, E. I., and L. A. Underkofler. 1947. Oxidation of polyhydric alcohols by Acetobacter suboxydans. Iowa State Coll. J. Sci. 21:251-270.

18. Gillis, M., and J. De Ley. 1980. Intra- and intergeneric similarities of the ribosomal ribonucleic acid cistrons of Acetobacter and Gluconobacter. Int. J. Syst. Bacteriol. 30:7-27.
19. Gosselé, F., J. Swings, and J. De Ley. 1980. Growth factor requirements of Gluconobacter. Zentralbl. Bakteriol. Mikrobiol. Hyg. 1:348-350.

20. Gosselé, F., J. Swings, K. Kersters, and J. De Ley. 1983. Numerical analysis of phenotypic features and protein gel electropherograms of Gluconobacter Asai 1935 emend. mut. char. Asai, lizuka, and Komagata 1964. Int. J. Syst. Bacteriol. 33:65-81.

21. Greenfield, S., and G. W. Claus. 1972. Nonfunctional tricarboxylic acid cycle and the mechanism of glutamate biosynthesis in Acetobacter suboxydans. J. Bacteriol. 112:1295-1301.

22. Grimont, P. A., M. Y. Popoff, F. Grimont, C. Coynault, and M. Lemelin. 1980. Reproducibility and correlation study of three deoxyribonucleic acid hybridization procedures. Curr. Microbiol. 4:325-330.

23. Johnson, J. L. 1973. Use of nucleic-acid homologies in the taxonomy of anaerobic bacteria. Int. J. Syst. Bacteriol. 23:308-315.

24. Johnson, J. L. 1981. Genetic characterization, p. 450-472, In P. Gehardt, R. G. E. Murray, R. N. Costilow, E. W. Nester, and W. A. Wood (ed.), Manual of methods for general bacteriology. American Society for Microbiology, Washington, D.C.

25. Kersters, K., and J. De Ley. 1963. The oxidation of glycols by acetic acid bacteria. Biochim. Biophys. Acta 71:311-331.

26. Lachance, M. 1980. Simple method for determination of deoxyribonucleic acid relatedness by thermal elution in hydroxyapatite microcolumns. Int. J. Syst. Bacteriol. 30:433-436.

27. Loitsyanskaya, M. S., G. V. Pavlenko, and A. I. Ivchenko. 1979. Taxonomy of acetic acid bacteria. Mikrobiologiya (Engl. Transl.) 48:545-551.

28. Mandel, M., L. Igambi, J. Bergendahl, M. L. Dodson, Jr., and E. Scheltgen. 1970. Correlation of melting temperature and cesium chloride buoyant density of bacterial deoxyribonucleic acid. J. Bacteriol. 101:333-338.

29. Rigby, P. W. J., M. Dieckmann, C. Rhodes, and P. Berg. 1977. Labeling deoxyribonucleic acid to high specific activity in vitro by nick translation with DNA polymerase I. J. Mol. Biol. 113:237-251.

30. Rohrbach, K. G., and J. B. Pfeiffer. 1975. The field induction of bacterial pink disease in pineapple fruit. Phytopathology 65:803-805.

31. Rohrbach, K. G., and J. B. Pfeiffer. 1976. The interaction of four bacteria causing pink disease of pineapple with several pineapple cultivars. Phytopathology 66:396-399.

32. Selin, Y. M., B. Harich, and J. L. Johnson. 1983. Preparation of labeled nucleic acids (nick translation and iodination) for DNA homology and rRNA hybridization experiments. Curr. Microbiol. 8:127-132.

33. Shimwell, J. L., J. G. Carr, and M. E. Rhodes. 1960. Differentiation of Acetomonas and Pseudomonas. J. Gen. Microbiol. 23:283-286,

34. Skerman, V. B. D., V. McGowan, and P. H. A. Sneath (ed.). 1980. Approved lists of bacterial names. Int. J. Syst. Bacteriol. 30:225-420.

35. Swings, J., M. Gillis, K. Kersters, P. DeVos, F. Gosselé, and J. De Ley. 1980. Frateuria, a new genus for Acetobacter aurantius. Int. J. Syst. Bacteriol. 30:547-556.

36. Vaughn, R. H. 1942. The acetic acid bacteria. Wallerstein Lab. Commun. 5-6:5-26.

37. White, S. A., and G. W. Claus. 1982. Effect of intracytoplasmic membrane development on oxidation of sorbitol and other polyols by Gluconobacter oxydans. J. Bacteriol. 150:934-943. 